\title{
INTERNATIONALIZATION OF PRIMARY PUBLIC SECURITIES MARKETS
}

\author{
HAL S. SCOTT*
}

I

\section{INTRODUCTION}

In fully internationalized securities markets, issuers in public primary markets should be able to issue securities to investors worldwide using one set of optimal distribution procedures and disclosure documents, and subject to one set of liability standards and enforcement remedies. Rules in which the benefits outweigh the costs are optimal. Optimal standardized issuance ("OSI") across borders would reduce the costs of issuing securities that are in international demand, a benefit that would be shared by both issuers and investors. Also, OSI would result in more perfect competition in the issuing market for such securities (just as in the goods market) and a more efficient allocation of capital worldwide. OSI is only relevant when there is sufficient investor demand for a public international distribution. This article is concerned only with those cases. The significant growth of registered offerings of foreign issuers in the United States, from seventy-eight in 1990 to 526 (with a total value of $\$ 145.9$ billion) in 1998 , is a strong indication of such investor demand.

This article focuses on public primary markets rather than public secondary markets. While the two markets are related-publicly distributed securities are invariably listed and traded in public secondary markets-they are not the same. Public securities are initially distributed through an underwriting process where securities are sold to investors by the issuer through underwriters; thereafter, the securities are traded in the secondary market. Primary market distributions play a crucial part in the allocation of capital. Investors purchasing in primary markets, as opposed to secondary markets, cannot necessarily rely on prices set in deep liquid markets where rational expectations of the value of the securities have been incorporated into the price. ${ }^{2}$ Additionally, public primary

Copyright $\odot 2000$ by Hal S. Scott

This article is also available at http://www.law.duke.edu/journals/63LCPScott.

* Nomura Professor of International Financial Systems, Harvard Law School.

1. See 1 Edward Greene et Al., U.S. Regulation of the InTERnAtional Securities AND DERIVATIVE MARKETS $§ 1-1$ (5th ed. 2000).

2. In arguing for a "market" approach to international securities regulation, Roberta Romano has advocated a system where the governing rules for a foreign issuer in U.S. markets would be the laws of the issuer's country of incorporation. Romano contends that such a regime would encourage foreign firms to list on U.S. exchanges. This, in turn, would have the effect of reducing the transaction costs facing the U.S. investor who wished to purchase foreign securities as they would be able to purchase them directly in the U.S. markets without having to incur the costs involved in purchasing shares on a foreign exchange. See Roberta Romano, Empowering Investors: A Market Approach to Securities 
markets involve purchases by individual investors; indeed, issuers make such distributions in order to reach these investors. While initial public offerings ("IPO"s) — an important part of the public primary market—are heavily dominated by institutional investors, individual investors participate significantly in these markets, as well.

This article assumes that there is no conflict between having standardized and optimal disclosure rules. Merritt Fox, to justify his issuer nationality approach, argues to the contrary when he raises the possibility that the socially optimal level of disclosure may differ for different countries. ${ }^{3}$ He argues, in effect, that the optimal level of disclosure in Germany and Japan, where capital has been traditionally allocated mainly through banking markets, may be lower than in the United States, where securities markets have played a more important role. ${ }^{4}$ However, in major markets, including Germany and Japan, securities markets currently play an important enough role that those countries care about how they allocate capital. Securities markets in these countries, as compared to banking markets, are gaining importance. Further, even if one should be more tolerant of less disclosure in Germany, such a rule would only affect allocation of capital within Germany. Such tolerance would not be appropriate in an international context where the concern is with allocation among issuers of different countries. If Deutsche Telekom raises significant capital outside Germany, we should be concerned with choosing the right set of rules for the world, not just Germany.

Part II of this article discusses the current obstacles to achieving OSI. It argues that the imposition of U.S. rules for disclosure, distribution, and enforcement, within and to some extent outside the United States, impedes the achievement of OSI. It also argues that the solution is not merely to abolish mandated disclosure. The article then proceeds to examine options for dealing with the problem. Parts III and IV, respectively, examine and then reject harmonization and various versions of mutual recognition as solutions. Part V examines the structure of U.S. Regulation $\mathrm{S}$ and restrictions on use of the Internet. Part VI proposes that relaxation of these rules can substantially contribute to establishing OSI for the issuance of foreign securities. Part VII is a conclusion.

\section{THE OPTIMALITY OF U.S. DisclosuRE RULES}

Currently, OSI is not achievable in public securities markets, largely because the United States conditions issuance in its territory-and to some significant extent to U.S. investors outside its territory-on compliance with its unique set

Regulation, 107 YALE L.J. 2359, 2418-20 (1998). Romano's argument is basically aimed at the secondary, rather than the primary, market.

3. See Merritt B. Fox, The Political Economy of Statutory Reach: U.S. Disclosure Rules in a Globalizing Market for Securities, 97 MICH. L. REV. 696, 757 (1998).

4. See id. at 760 . 
of distribution procedures, disclosure documents, and enforcement rules. It is well known that this practice has deterred primary issuers from distributing securities in U.S. markets and to U.S. investors. Standardized issuance ("SI") can be achieved if issuers are willing to abide by U.S. rules, because these rules are tougher in most material respects than those in other jurisdictions. But it is unlikely that these rules are optimal. Because the United States is the predominant source of worldwide capital, U.S. rules have either substantially fractionated international public securities markets by precluding U.S. issues, or resulted in non-optimal standardized distributions.

\section{A. The Market Test of Optimality}

The fact that the international unregulated private placement market does not always demand U.S. public market documentation reveals that the level of disclosure required by the United States is not optimal. Instead, the international market generally has adopted what market participants call "international" documentation or rules, developed by issuers, underwriters, and institutional investors. ${ }^{5}$ The United States justifies its more complicated disclosure rules by claiming that they are for the benefit or protection of the less sophisticated investor. It is unlikely, however, that relatively unsophisticated individual investors can make use of more or different information than sophisticated investors; indeed, because of their lack of sophistication, they can make less use of such information. To the extent that the rationale for disclosure levels is the desirability of accurate market prices, sophisticated investors have just as much incentive, and probably more, in having such accuracy.

It is more plausible to argue that individual investors need to have information presented to them in a different manner than do sophisticated investors. This idea is central to the SEC's advancement of the "Plain English" requirement. ${ }^{6}$ Sophisticated investors, it is argued, do not need to have things spelled out because they bring more background to their reading. Yet this argument is faulty as well, because most individual investors do not read prospectuses; the information in the prospectuses is predigested for them by analysts or advisors. Those who do read prospectuses are likely to be fairly sophisticated, even if they would not qualify as private placement investors. ${ }^{7}$ In any event, distinguishing between style and substance, we can use the substance of disclosure in the private market as a benchmark. It is important to emphasize that private market disclosure standards arise out of commercial practice and not law. In-

5. Emails from Edward F. Greene, Partner, Cleary, Gottlieb, Steen \& Hamilton, to Hal S. Scott (Aug. 16, 1999 and Sept. 1, 1999) (on file with author).

6. Plain English Disclosure, Security Act Release No. 7497, Exchange Act Release No. 39,593, 63 Fed. Reg. 6370 (Feb. 6, 1998).

7. The claimed virtues of the Plain English approach have not gone unchallenged. See Kenneth B. Firtel, Note, Plain English: A Reappraisal of the Intended Audience of Disclosure Under the Securities Act of 1933, 72 S. CAL. L. REV. 851, 890 (1998) (noting that the theory underlying the "plain English" regulation involves risks to both the unsophisticated investor and the financial professional owing to the fact that "[i]f an issuer attempts to use simple words to explain complex concepts, then inevitably something will be left out"). 
deed, one cannot go anywhere to look them up-probably the best one could do is to reverse engineer the rules from the actual forms lawyers use to create their documentation.

Further research is necessary to determine how closely the international standard matches existing U.S. rules for public offerings. One clear difference does exist: There is no U.S. GAAP reconciliation under the international standard. If the United States were to accept the International Accounting Standards Committee ("IASC") standards as an alternative to U.S. standards, as now seems quite probable, this difference may become immaterial. Apart from accounting, it appears that the international standard may be quite close to U.S. rules for some offerings, particularly IPOs. But for secondary offerings ${ }^{8}$ of widely traded companies-which regularly report material information to the market - there may be a significant difference between international standards and U.S. rules. For example, in a recent private equity offering for Hong Kong and Shanghai Bank, documentation was minimal because the market believed it already had enough information. If private market disclosure based on actual practices is used as a basis for determining the adequacy of public disclosure, the level of required disclosure would depend on various characteristics of the issue-for example, debt versus equity, IPO versus secondary, and big versus small-as well as the nature of the issuer-for example, reporting versus nonreporting and regulated (for example, banks) versus non-regulated.

The solution to different distribution and enforcement rules is much less clear. It is entirely rational to have different distribution rules for institutional and individual investors. For example, one may have legitimate concerns that individual investors could be more influenced than institutional investors to buy securities based on underwriter research reports disseminated during the distribution period. It also may be entirely rational to have different enforcement rules for public and private markets. For example, the feasibility of enforcement by individuals in public markets may depend on the prospect of damages in a class action suit, while in private markets, the necessity of repeat dealings may adequately deter violations. ${ }^{9}$ Unfortunately, there is no reliable private market for distribution rules or enforcement to use as a benchmark for the optimality of rules.

An issuer can generally deal with diverse national distribution requirements in three ways: (1) abstain entirely from issuing in the U.S. market; (2) distribute in foreign markets under foreign rules and in the U.S. market under U.S. rules, which might result in the distribution being later in the United States than abroad; or (3) refrain from issuing marketing materials, other than a U.S.compliant prospectus, in any market until the registration statement is effective in the United States. Option 1 clearly results in segmented markets, as no securities are issued in the United States. Option 2 also results in segmentation, be-

8. When I use the term secondary offering in this article, I mean any offering that is not an IPOthat is, any additional issue of securities by the issuer.

9. See Douglas G. Baird et Al., Game TheOry AND the Law 159-86 (1994). 
cause price competition introduced by U.S. distributions is not available during earlier distributions in other countries. Option 3 achieves a standardized distribution, but at the cost of deferring the distribution until the U.S. effective registration date. Option 3 could increase investor cost if deferred marketing increases issuer distribution cost, and may not be justified if it decreases investor welfare overall. This is a general problem with any system of mandated harmonized rules, as discussed in Part III below.

The SEC is largely responsible for engineering the current state of affairs. It has acted from the best of motives-the protection of U.S. investors. It seeks generally to ensure that investors are well-informed before making investment decisions and believes that rigorous disclosure is necessary to protect the reputation of U.S. capital markets. The SEC believes in the virtues of standardized primary issuance markets, but insists that U.S. law set the standard.

In my view, the SEC has pursued a limited vision of investor welfare. In the desire to protect individual investors (visions of widows and orphans spring to mind), the SEC may have sacrificed investor welfare as a whole. While some number of investors may make better investment decisions as a result of SEC rules, investor welfare as a whole is decreased by the inability to achieve standardized rules. Lack of standardization imposes higher costs on issuers, which are passed on to investors through higher prices for capital. As in other areas of consumer protection, the benefits to particular consumers should be weighed against the costs to consumers as a whole.

\section{B. Claims That Disclosure is Unimportant to Investor Welfare}

Some authors have taken the extreme view that investor welfare is largely unaffected by the level of disclosure. They argue that investors will take the level of disclosure into account when purchasing securities. Investors will discount the price of securities for lack of disclosure because securities with less disclosure will be more risky than those with more disclosure. ${ }^{10}$ This argument is entirely unconvincing, particularly in primary markets. First, there is generally no way for an investor, sophisticated or otherwise, to know that he is missing information and to attach an appropriate discount to that risk. ${ }^{11}$ For example, an investor has no way of knowing that an issuer failed to disclose material

10. See Stephen J. Choi \& Andrew T. Guzman, Portable Reciprocity: Rethinking the International Reach of Securities Regulation, 71 S. CAL. L. REV. 903, 906 (1998) (arguing that "[i]nvestors ... will discount the price they are willing to pay for securities based on the regime under which the securities are issued or traded"); Fox, supra note 3, at 732 n.86 (arguing that "each investor will receive the same riskadjusted expected rate of return whatever issuer's shares she purchases, whether the issuer discloses at a high level or a low one" if share prices equal the present value of their future income stream and investors have a worldwide set of issuers to choose from); Romano, supra note 2, at 2366-67 (arguing that issuers "will bear the cost of operating under a legal regime inimical to investor interests, and they will therefore select the regime that maximizes the joint welfare of promoters and investors").

11. Also, as Joel Trachtman points out in Regulatory Competition and Regulatory Jurisdiction in International Securities Regulation 15-16 (Sept. 22, 1999) (Working Paper, on file with author), under the Tiebout model for regulatory competition, investors must be fully informed about the securities laws of all jurisdictions, a condition which obviously cannot be fulfilled in the case of individual investors. 
information, such as a design flaw. ${ }^{12}$ Even if the investor knows that the issuer failed to disclose a particular type of information, such as segmented line of business information, the investor does not know that this means the issuer is more risky. The issuer may have chosen not to disclose such information because disclosure would aid competitors, rather than because it would show that its earnings were undiversified. One could try to finesse this basic problem by arguing that the price of a security reflects whatever judgments, however imperfect, the market makes about the adequacy of disclosure. So while the discounting may not be perfect—no discount ever is-it does occur.

Second, the discounting argument only works if a market generally has adequate disclosure, and that the price of an individual security based on inadequate disclosure can be discounted; that is, that there is a market baseline against which to measure the discount. However, if the market provides generally inadequate information, such discounting becomes impossible. In addition, whatever persuasiveness this argument may have in secondary markets, it fails in primary markets because the price of the security is not generally set by the market, but by the issuer and the underwriter. Furthermore, the discounting argument ignores the impact of such discounts on the capital formation process. Due to the riskiness of markets without optimal disclosure rules, there will be underinvestment in such markets. ${ }^{13}$ At the macro level, worthwhile projects may go without funding; at the micro level, investor preferences for security investments with less risk will go unsatisfied. In theory, markets suffering from underinvestment due to sub-optimal disclosure should, in the long term, increase disclosure requirements. But increasing disclosure requirements leaves no protection for investors in the short term. Moreover, countries may fail to adopt optimal disclosure rules because of regulatory capture by influential issuers or inadequate resources.

Third, these discounting arguments ignore the problem of over-disclosure. As argued above, if issuers are required to disclose information where the costs of providing the information exceed the benefits to investors, investor welfare is decreased. Investors cannot avoid this problem by simply refusing to buy stocks issued in markets demanding too much disclosure if such markets are sizable,

12. Frank H. Easterbrook and Daniel R. Fischel rejected the inability to discount as grounds for mandating disclosure, stating that "[o]nce the firm starts disclosing it cannot stop short of making any critical revelation, because investors always assume the worst. It must disclose the bad with the good, lest investors assume that the bad is even worse than it is." Frank H. Easterbrook and Daniel R. Fischel, Mandatory Disclosure and the Protection of Investors, 70 VA. L. REV 669, 683 (1984). This is nonsense. Will investors assume that cars will self-destruct just because a manufacturer has not revealed a design flaw that investors have no reason to believe exists? I agree, however, with the authors that third-party effects might deter disclosure by issuers of information they might readily agree to provide if such disclosure were mandated for everyone.

13. Lack of reliable information is already a classic problem in developing markets and one that accounts for underinvestment. 
like those of the United States, and attractive on dimensions other than disclosure. $^{14}$

A cousin of the discounting argument is the contention that the level of disclosure does not matter to investors who have diversified portfolios. As with the discount argument, this contention has very limited applicability to the primary market, as diversified portfolios would not usually contain new issues (particularly not IPOs). Further, there are basic problems with the diversification argument even for the secondary market.

The term "diversification" in this context is not very clear. The conventional notion of a portfolio diversified for the risks of a specific issuer-for example by type of business and country of operations-requires disclosure to obtain the information necessary to diversify if one is picking stocks (as opposed to buying index funds). In constructing a diversified portfolio, one seeks lack of co-variation in the price of the securities. This could be done mechanically based only on some period of past price performance, without knowing anything about the issuers of securities. But as we know, past is not always, and perhaps not even usually, prologue. Suppose, for example, that some industries had fixed the $\mathrm{Y} 2 \mathrm{~K}$ problem and others had not and could not. The past performance and co-variation of the non-compliant industries would not be a reliable predictor of future performance. Investors need current information in order to diversify intelligently.

Accurate pricing of portfolios affects the attractiveness of holding investments, whether an index fund or an actual portfolio of all stocks (assuming no budget constraint). Even if the portfolio is perfectly diversified, investors still have a substantial interest in the value of the portfolio, and the price of the portfolio will certainly be affected by the adequacy of disclosure. Indeed, if investors believe that stocks-or the index funds composed of such stocks-are more risky because of lack of disclosure, they will hold less stock and more of some other financial asset. This is not optimal from the investor's point of view, however, because he would prefer to hold more stocks if disclosure were more optimal.

There could be another notion of a diversified portfolio with respect to the level of disclosure applicable to particular securities. The claim would be that disclosure is not important if one owns a portfolio of securities diversified with respect to the disclosure rules themselves. But holding a portfolio diversified as to disclosure rules does not, as is the case with specific performance risk, diversify the investor out of the risk of non-disclosure. The theory of diversification with respect to risk is based on constructing a portfolio in which the performance of the securities is imperfectly (if possible, even negatively) correlated. One cannot ensure that the actual valuation of securities under different disclo-

14. See James D. Cox, Regulatory Duopoly in U.S. Securities Markets, 99 Colum. L. REV. 1200, 1233-1237 (1999) [hereinafter Cox, Regulatory Duopoly] (formulating his own excellent critique of reliance on the discounting mechanism). 
sure regimes is imperfectly correlated, because the value of securities is determined by the performance of the firms, not disclosure rules.

Finally, even if the discounting mechanism worked perfectly to compensate investors and penalize issuers for inadequate disclosure, the lack of disclosure would still result in the imperfect allocation of capital. That is, optimal levels of disclosure help to ensure that capital finds its most productive use.

This article next explores three alternatives for possibly dealing with the need for OSI: (1) harmonization, under which countries of the world agree on a common set of rules, whether U.S. rules as the SEC would have it, or some other set of rules; (2) mutual recognition, under which participating countries defer to the validity in their territory of the rules of other countries, along the lines adopted in the European Union, and to a limited degree under the U.S.Canadian Multijurisdictional Disclosure Statement ("MJDS") regime; and (3) off-shore free zones, where issuers are free to issue securities to investors from any country under one set of rules. It concludes that off-shore free zones are the best and most realistic alternative.

III

\section{HARMONIZATION}

Under the harmonization alternative, every nation in the world would adopt one set of rules for the primary issuance of securities. Efforts along these lines are already well under way. The International Organization of Securities Commissioners ("IOSCO") has formulated a set of disclosure rules ${ }^{15}$ and the International Accounting Standards Committee ("IASC") has promulgated international accounting rules. ${ }^{16}$ However, there are several problems with this harmonizing effort. The major problem is that there is no reason to assume that the world's regulators would choose an optimal level of disclosure, even if they could agree on a single disclosure standard, particularly since the United States is likely to insist that world standards be close to its own, a standard that may be far from optimal. Indeed, harmonization of disclosure rules at a non-optimal level could make investors worse off, since optimal rules in some markets-for example, possibly the United Kingdom-would be replaced by non-optimal harmonized rules. Unlike the situation today, one would not have the choice of avoiding U.S. type public distribution rules just by foregoing a public U.S. distribution. There are other problems as well.

First, it is highly doubtful that international agreement can be achieved. IOSCO has been able to reach agreement on some basic disclosure issues where there are few national differences and the basic rules are consistent with current

15. See InTERnational Org. OF SEC. COMM'Ns, InTERnational Disclosure Standards FOR CROSS-BORDER OFFERINGS AND INITIAL LISTINGS BY FOREIGN ISSUERS (1998).

16. See generally INTERNATIONAL ACCOUNTING STANDARDS COMM., INTERNATIONAL DISCUSSION PAPER: SHAPING IASC FOR THE FUTURE (1998). The need for foreign issuers to comply with U.S. accounting rules in order to access the U.S. market (GAAP reconciliation) has been a substantial deterrent to entering the U.S. market. 
U.S. practice-such as requirements to identify directors, senior management, and advisers or to provide key information about the company's financial position. However, IOSCO has been unable to reach agreement in other areas where the difference between nations is significant, such as the need for segmented market reporting, the permissibility of making forecasts or projections, and the permissibility of director indemnification. In September 1999, the SEC adopted changes, effective September 2000, to its non-financial statement disclosure requirements to conform more closely to the International Disclosure Standards endorsed by IOSCO in September 1998..$^{17}$ The Standards, however, only cover the fundamental disclosure topics discussed above and not the more contentious areas. The SEC trumpeted the adoption of the IOSCO rules as the equivalent of an "international passport" that will gain issuers access to U.S. markets. ${ }^{18}$ At the same time, one law firm, commenting on the adoption at the proposal stage, said that the passport holder will still need a U.S. visa that is costly and time-consuming to obtain. ${ }^{19}$

Second, no effort has been made to date to achieve standardization with respect to the more difficult area of distribution procedures and enforcement. Even assuming that every country agreed to harmonize disclosure documents, primary markets would still be segmented. For example, in the United States, an issuer (or underwriter or dealer) cannot generally distribute marketing materials, other than those contained in a "prospectus," before a registration statement becomes effective. ${ }^{20}$ Other countries do not have the same requirement. There is no current prospect for harmonizing distribution rules.

Likewise, no effort has been made to achieve standardization with respect to enforcement. Standardized enforcement would require countries to have similar enforcement remedies, both administrative and private, and to apply such remedies with similar effectiveness. Lack of standardized enforcement can also lead to segmented markets or increased distribution costs. A significant number of foreign issuers have reportedly avoided U.S. public markets because of the stiff enforcement remedies employed by the SEC-including potential criminal liability-and the prospect of costly private class action suits. ${ }^{21}$ The lack of effort to standardize distribution procedures and enforcement reflects the extreme difficulty of achieving consensus as to what the standards should be.

A third problem with harmonization involves the necessity of interpreting or updating agreements in a timely fashion. This has been a significant issue in

17. See International Disclosure Standards, Securities Act Release No. 7745, Exchange Act Release No. 41,936, 64 Fed. Reg. 53,900 (Oct 5, 1999).

18. Id.

19. See Comment from Sullivan \& Cromwell to Jonathan G. Katz, Secretary, Securities and Exchange Commission (last visited Apr. 12, 1999), <http://www.sec.gov/rules/proposed/s7399/sulliva1. htm>.

20. See James Cox et Al., Securities Regulation: Cases and Materials 276-99 (2d ed. 1997) [hereinafter SECURITIES REGULATION].

21. See Howell Jackson and Eric Pan, Regulatory Competition in International Securities Markets: Evidence from Europe in 1999, 50 (2000) (preliminary draft on file with author). 
IASC's work on the promulgation of international accounting standards. Work on the basic twelve standards was completed in December 1998. The standards have already been accepted by the London Stock Exchange and almost all other European exchanges. However, the SEC and the Financial Accounting Standards Board ("FASB") have balked at allowing their use in the United States until agreement on a future governance system for interpreting and updating such standards is achieved. ${ }^{22}$ While such agreement is now on the horizon, a governance structure for disclosure standards, not to mention distribution and enforcement standards, would be much more daunting. It is hard to envision IOSCO performing this function, due to its diverse membership (members come from ninety-seven jurisdictions), and the reluctance of national sovereigns to delegate such sensitive matters to an international organization. Even if a forum could be devised to take charge of harmonized rules, the serious question of whether one would want to entrust any international body with that kind of authority would remain; this would raise the specter of the Uberregulator. ${ }^{23}$

A fourth problem with harmonization is that it can stifle innovation. An important source of regulatory reform and change is competition among national authorities and the possibility of escaping national regulation (to some extent) by engaging in offshore transactions. It would be better to achieve standardization for particular issues of public securities without requiring that all issues of securities abide by the same rules, particularly when, as argued above, harmonized rules are likely to be non-optimal.

\section{MUTUAL RECOGNITION}

Mutual recognition is a system in which host countries recognize the validity of using other countries' rules to issue securities in the territory of the host countries. For example, under the MJDS regime adopted in $1991,{ }^{24}$ the United States permits Canadian companies to issue securities in the United States under Canadian rules, and Canada permits U.S. companies to issue securities in Canada under U.S. rules, albeit with some very important exceptions. ${ }^{25}$ Additionally, the European Union permits firms in one member state (the home

22. See Michael Peel, Accord Puts Common World Standards Drive Back on Track, FIN. TIMES, Nov. 19, 1999, at 14; Lucinda Kemeny, Global Watchdog Under Threat, ACCT. AGE, Oct. 7, 1999, at 5.

23. See Joseph A. Grundfest, Internationalization of the World's Securities Markets: Economic Causes and Regulatory Consequences (Stanford Law \& Economics Working Paper, 1990). More recently, Uri Geiger has suggested the creation of a "Global Coordinator" to implement harmonized rules. See Uri Geiger, Harmonization of Securities Disclosure Rules in the Global Market: A Proposal, 66 FORDHAM L. REV. 1785, 1800-05 (1998).

24. See Multijurisdictional Disclosure and Modifications to the Current Registration and Reporting System for Canadian Issuers, Securities Act Release No. 6902, Exchange Act Release No. 29,354, Trust Indenture Act Release No. 2267, 56 Fed. Reg. 30,036 (July 1, 1991) [hereinafter MJDS].

25. In 1999, Canadian firms accounted for $38 \%$ of the 1116 international offerings in the United States. See Stephen Handelman, Newly Limited Partnership; Canada Could Lose Its Special Status in U.S. Capital Markets, TIME, Dec. 13, 1999, at 29. 
state) to issue securities throughout the Union (within host states), under home state rules. However, neither of these arrangements has been totally satisfactory.

\section{A. MJDS}

The MJDS regime is limited in a number of ways. Because it only covers equity and investment-grade debt of companies with over $\$ 75$ million in public float, it is not available for IPOs. Also, for issuance in the United States, the issuer must be a Canadian company (incorporated in Canada) or a "foreign private issuer" (or Crown corporation). A foreign private issuer is defined in Rule 3b-4 of the Exchange Act and Rule 405 of the Securities Act to include all foreign issuers other than: (1) foreign governments; and (2) foreign issuers that have: (a) more than fifty percent of their outstanding voting securities directly or indirectly owned of record by residents of the United States; and (b) U.S. citizens or residents making up a majority of their executive officers and directors, more than fifty percent of their assets located in the United States, or their business administered principally in the United States. ${ }^{26}$

Only real Canadian companies are permitted to use MJDS. Technically, however, a company whose operations and management were entirely based in Nigeria could, if it was incorporated in Canada (assuming such incorporation were permitted under Canadian law), meet the requirements of Canadian incorporation for a foreign private issuer. Despite this technicality, there does not seem to be a case of the use of Canadian rules by companies based outside Canada, and it is highly likely that U.S. and Canadian securities officials would prevent this from happening. ${ }^{27}$

While the MJDS generally permits qualified issuers to use Canadian disclosure rules, certain important exceptions are made: financial statements must be reconciled to U.S. GAAP, auditors must be independent according to U.S. standards, documents must be in English (they are in French in Quebec), and there must be disclosure on indemnification provisions regarding directors, officers, and controlling persons (Canadian law does not require this).

More basically, the MJDS only deals with disclosure standards; it does not cover distribution rules or liability. For example, U.S. requirements on delivery of the prospectus, safe harbor provisions on advertisements, and rules on the publication of opinions and recommendations still apply. In addition, U.S. liability rules for public issues, most importantly Sections 11 and 13 of the Securities Act of 1933 and Rule 10b-5 under the Securities and Exchange Act of 1934, still apply with one important exception. A registration statement will not be considered misleading or fraudulent simply because it does not contain information required by U.S. rules. As long as an issuer complies with Canadian standards (subject to the exceptions noted above), as construed by Canadian

26. See 17 C.F.R. $\$ 240.3 b-4$ (2000); 17 C.F.R. $\$ 230.405$ (2000).

27. Telephone conversation with Craig Broad, Cleary, Gottlieb, Steen \& Hamilton (Jan. 25, 2000). 
authorities, the issuer is in compliance with U.S. law. ${ }^{28}$ It is important to note that public enforcement of Canadian standards in connection with U.S. issues has been effectively delegated to Canada. Only Canadian authorities review the Canadian registration statements used in the United States.

The SEC has been reported to be considering the elimination of the MJDS, apparently out of concern that Canadian disclosure standards, and particularly the enforcement of those standards by Canadian authorities, are not as rigorous as those of the United States. ${ }^{29}$ The SEC, however, is apparently going to justify the change on the grounds that special bilateral disclosure arrangements were inconsistent with the need for uniform rules for foreign issuers. ${ }^{30}$

\section{B. European Union and Mutual Recognition}

As part of the objective of creating a single market within its states, the European Union permits an issuer to offer its securities on an E.U.-wide basis, subject only to the disclosure rules of its home state and compliance with certain minimum E.U. standards. Thus, for example, a French company could offer its securities throughout the European Union, which comprises Austria, Belgium, Denmark, Finland, France, Germany, Greece, Ireland, Italy, Luxembourg, the Netherlands, Portugal, Spain, Sweden, and the United Kingdom. For securities on exchanges, the Listings Particulars Directive applies, and for public offerings of unlisted securities, the Public Offering Prospectus Directive ("POP") applies. ${ }^{31}$ The European Union does not proscribe standard distribution rules or liability rules; these matters are left to host states.

Forum shopping for disclosure rules within the European Union is limited by the Listings Directive requirement that a company must list first in the country of its registered office, if it is listing there at all. Thus, a French company seeking to list its securities on the Paris Bourse and other exchanges would have to do so in Paris first, with the result that its securities would be subject to French disclosure rules throughout the European Union. If the French company were not listing in France, however, it could list in any other country first and be subject to that country's rules. No forum shopping constraint applies to the distribution of entirely unlisted securities. ${ }^{32}$

A 1998 report of the U.K. Treasury, Public Offers of Securities, finds that there have been very few cross-border public offerings in the European Union despite the promise of the Directives. ${ }^{33}$ Indeed, it appears that the 1999 and

28. See MJDS, supra note 24, at 30,049.

29. See Edward Alden, Canadians Mobilise Over Loss of MJDS, FIn. TIMES, Dec. 1, 1999, at 34.

30. See id.

31. See generally Manning Warren, Regulatory Harmony in the European Communities: The Common Market Prospectus, 16 BROOK. J. INT'L L. 19 (1990).

32. See Brian J. Fahrney, State Blue Sky Laws: A Stronger Case for Federal Pre-Emption Due to Increasing Internationalization of Securities Markets, 86 Nw. U. L. REV. 753, 772 n.155 (1992).

33. Her MAJesty's Treasury, Public OFFERS OF SECurities (1998) (visited Oct. 25, 2000) $<$ http://www.hm-treasury.gov.uk/pub/html/reg/posec.html $>$ [hereinafter PUBLIC OFFERS OF SECURITIES]. 
2000 Deutsche Telekom distributions are the only instances of a European-wide public offering. ${ }^{34}$ Obstacles to such offers include the need to make translations and the need to include information specific to a country, such as paying agents, the income tax system, and the method of notification of investors (together with the cost of the legal advice required to make this determination). With listed securities, host states impose additional requirements despite the provisions of the Listing Directive. While the European Union has undertaken to perfect its system,${ }^{35}$ concrete corrective measures have yet to be advanced by the European Commission. ${ }^{36}$

The U.K. Treasury also alludes to another possible cause of the low usage of the Directives, even in connection with IPOs: Large companies distribute and list their securities in one member state and allow investors to come to that state to buy and trade the securities. The very premise of the mutual recognition regime-that public offerings need to be distributed in several territories-may be wrong. As long as investors (or their representatives) can buy the issue somewhere within the European Union, there may be no need to offer the security in multiple territories. A single market could be achieved simply by ensuring that member states not apply their rules to their own investors extraterritorially (as does the United States). In the European Union, member states do not apply securities laws extra-territorially, so this is not a problem. I develop this possibility at more length as part of the off-shore free-zone option in Part VI.

One additional reason for the low usage of the cross-border Directives may be the wide scope for private placements within the European Union and the relative ease of the resale of privately distributed securities to public investors. Many countries have broad exemptions from disclosure requirements for sales to sophisticated investors or to market professionals. In addition, the Directives grant a general exemption to "eurosecurities" that are: (1) underwritten and distributed by a syndicate at least two of the members of which have their registered offices in different states (multiple state underwriters); (2) offered on a significant scale in one or more states other than that of the issuer's registered office (distribution in state other than issuer's); and (3) subscribed for or initially acquired only through a credit institution or other financial institution (sold to banks). ${ }^{37}$ Eurosecurities are exempted from the E.U. disclosure requirements if

34. Often, however, there are European-wide private placements combined with retail distributions in the issuer's home market, so-called "international style" offerings. Many of these offerings use U.S.-type public documentation, due to the demands of the investors, even though such documentation is not required. See Jackson \& Pan, supra note 21. Deutsche Telekom made another European-wide retail distribution, as part of a worldwide retail distribution, in June 2000. See A. Ostrovsky \& U. Harnischfeger, Deutsche Telekom in Global Balancing Act, FIN. TIMES, May 15, 2000, at 33.

35. See Financial Services: ImPlementing the Framework For Financial Markets: ACTION PLAN (1999).

36. However, THE Forum OF European SECURITIES COMMISSIONS, A "European PASSPORT" FOR ISSUERS (May 10, 2000), has formulated proposals to deal with some of these issues.

37. See Hal S. Scott \& Philip A. Wellons, International Finance: Transactions, POLICY, AND REGULATION 312 (7th ed. 2000). 
they are not subject to "a generalized campaign of advertising or canvassing." Thus, a German company could issue securities underwritten by a bank syndicate, including Deutsche Bank and Barclays, and sell the securities to various banks in London, who might then resell them to individual investors (the proverbial Belgian dentists).

The "eurosecurities" exemption has been implemented in different forms in different member states. For example, Germany has said that the "canvassing" prohibition only applies to door-to-door sales, and not apparently to calls to clients. The Netherlands has said that a retail investor may be approached by a financial institution as long as this is not done systematically by way of a general campaign. Neither Germany nor the Netherlands has limited the "eurosecurities" exemption to particular types of securities, whereas Belgium has limited it to Eurobonds. ${ }^{38}$ The U.K. Treasury Report concludes that the "eurosecurities" exemption has not been relied upon much in practice because of the broad definition in some states of a generalized campaign of advertising, or because of restrictive definitions of "eurosecurities." In the United Kingdom, issues rely on private placement exemptions (offers to market professionals) rather than on the "eurosecurities exemption."

\section{Extending Mutual Recognition}

This Section considers three approaches to extending mutual recognition: (1) extending the MJDS to additional countries, specifically the United Kingdom; (2) recognizing home country rules of "efficient" markets; and (3) adopting a much broader version of mutual recognition, such as "portable reciprocity."

1. Extending the MJDS to the United Kingdom. One alternative for internationalizing securities markets would be to perfect mutual recognition by cutting down on its exceptions and extending the rule to other countries. Indeed, one simple solution might be for the United States to extend the MJDS, in a more complete form, to the United Kingdom. Today, the international importance of U.K. public rules is very small because, as discussed above, there are almost no pan-European public offerings. However, if E.U. obstacles to such offerings were removed, issuers might prefer to use U.K. rules for such offerings, and recognition of the U.K. rules by the United States would permit distribution of securities sold publicly in both Europe and the United States, and perhaps worldwide, under U.K. rules.

The United Kingdom would be a logical candidate for the MJDS extension, given its shared Anglo-Saxon tradition and English language with the United States and Canada. The lack of substantive difference between U.S. and Canadian rules was an important factor in the initial adoption of the MJDS; one study has shown that there is little difference between the substance of U.K.

38. Id.

39. Public OfFERS OF SeCURITIES, supra note 33, at $\S 5.23$. 
and U.S. disclosure rules. ${ }^{40}$ Indeed, it appears that the SEC considered the extension of the MJDS to the United Kingdom over a decade ago, only to reject it due to the SEC's concern with lax enforcement standards. With the advent of new, tougher securities law enforcement in the United Kingdom, under the Financial Supervisory Authority ("FSA"), this would be much less of a problem today.

However, this solution will probably not work for the following reasons. First, the MJDS system creates a basic inequity for domestic issuers. Under the MJDS, foreign issuers can use either their home country or U.S. rules, but U.S. issuers must use U.S. rules. Such inequities could create pressure to change U.S. domestic rules. ${ }^{41}$ Indeed, in the European Union, it was widely believed and accepted that the home-country approach would shortly lead to convergence of disclosure standards (to some optimal level) as domestic issuers pressured governments to change local rules. In the international context, such convergence is likely to be less acceptable, particularly to the United States. Thus, use of the MJDS is likely to result in long-term inequities for U.S. domestic issuers, who will be forced to compete for capital with foreign firms using more efficient disclosure rules.

Second, the MJDS as extended to the United Kingdom, would only permit "real" U.K. companies to issue securities under U.K. rules. As we have seen, only "real" Canadian companies can currently make use of the MJDS. The rationale for this limitation is probably one of enforcement. While it is true that the MJDS contemplates some enforcement by the United States, as by the application of Rule 10b-5, this is ex post rather than ex ante. The MJDS basically relies on Canada to monitor and enforce compliance with initial and ongoing disclosure requirements. If Nigerian companies, for example, were permitted to use Canadian rules to issue securities in the United States, how would Canadian authorities be able to enforce Canadian rules against Nigerian violators? One could imagine that submission to Canadian jurisdiction might be a condition for use of Canadian rules. But what would this mean in practice if the assets, management, and directors of the Nigerian issuers were outside Canada? ${ }^{42}$ More fundamentally, the United States would be concerned with whether Canada would have any substantial interest in enforcing its rules when the issuers were non-Canadian firms outside Canadian jurisdiction. Absent confidence in Canadian enforcement, the United States would not want to permit non-Canadian firms to issue securities in the United States under Canadian rules. As dis-

40. See Mario Fallone, Comparing Disclosure Requirements in the United States with those found in the United Kingdom (1999) (unpublished third year paper, Harvard Law School) (on file with the author).

41. See John C. Coffee, Jr., The Future as History: The Prospects for Global Convergence in Corporate Governance and Its Implications, 93 Nw. U. L. REV. 641, 672-73 (1999) (questioning whether the SEC can allow foreign issuers access to U.S. markets based on "even marginally relaxed financial standards," if it denies U.S. issuers the same ability).

42. Concerns about such jurisdictional issues are reflected in the current U.S. approach to the regulation of foreign mutual funds, for example requiring them to be offered through a U.S. vehicle. See 15 U.S.C. $\$ 80 a-7(d)(1994)$. 
cussed below, such enforcement problems are even more serious when considering broader choice in the use of disclosure rules.

If the MJDS were only applicable to "real" U.K. companies, its extension would not do much to achieve OSI. The potential attractiveness of the U.K. extension is not merely to allow U.K. companies to access U.S. markets, but to allow all issuers to access U.S. markets under U.K. disclosure rules. Given enforcement concerns, and given the limited ability of the United Kingdom to enforce its rules against non-U.K. firms, the U.K. extension has limited utility.

Third, the MJDS extension to the United Kingdom would do little to solve the problem of non-standardized distribution and enforcement rules. The MJDS, for example, provides that sales in the United States may not be made until registration forms are declared effective. The MJDS specifically rejected the rule that would have imported the Canadian practice of allowing underwriters to solicit expressions of interest from potential investors within two business days prior to filing a preliminary prospectus with Canadian securities regulators. $^{43}$ In addition, an MJDS extension would not result in standardized enforcement rules. Whereas primary responsibility for administrative enforcement is left with the home country (allowing the SEC to step in if necessary), liability standards (as they apply to compliance with the disclosure standards of the MJDS) and private enforcement remedies are governed by United States law. $^{44}$

2. Extending Mutual Recognition to Efficient Markets. In 1995, Ed Greene, Daniel Braverman, and Sebastian Sperber proposed a somewhat more ambitious and quite sensible extension of the mutual recognition principle. ${ }^{45}$ Under their approach, the United States would allow securities of foreign companies to be purchased in the United States under their home country disclosure rules if the home market for the securities in question were considered to be efficient, assuming that the home country gave reciprocal privileges to U.S. companies. The main criteria for making such a judgment would be whether the home market met: (1) minimum disclosure standards; (2) minimum periodic reporting requirements; (3) satisfactory rules preventing market manipulation and ensuring market transparency; and (4) minimum market capitalization and trading volume requirements. ${ }^{46}$ The premise of this approach is that "in certain markets outside the United States all material developments about a company could reasonably be expected to be made publicly available, and all publicly available information about the company could reasonably be expected to be reflected in the price at which its shares trade in the home market. ${ }^{\prime 4}$

43. See MJDS, supra note 24 , at 30,047 .

44. See id. at 30,049.

45. See Edward F. Greene et al., Hegemony or Deference: U.S. Disclosure Requirements in the International Capital Markets, 50 Bus. LAW. 413 (1995) [hereinafter Greene et al., Hegemony].

46. See id. at 438-39.

47. Id. at 436 . 
This proposal was basically aimed at secondary market trading, rather than primary public distributions. ${ }^{48}$ It is unlikely that the efficiency approach would work nearly as well in the primary public markets, which have no real "market" price. In the case of IPOs, by definition, no public market incorporating price information is available at the time of the distribution.

Even in the case of secondary distributions, the price of the issued stock will often be fixed, and therefore will not be purchased at a "market" price. Even if the price of a secondary issue is priced with reference to the market price, the price will not actually be the market price. At the time the stock is purchased, the purchaser will pay the fixed price rather than the market price.

This proposal also can be criticized because it creates inequities for U.S. issuers who continue to face the more onerous SEC requirements. The authors have several responses to this criticism, but none that are altogether convincing. ${ }^{49}$ First, they argue that U.S. companies would not be subject to any new requirements. This is true but does not squarely address the dual standard problem. Second, they argue that U.S. issuers would be at no greater disadvantage given the existing ability of U.S. investors to participate in primary offerings by non-U.S. issuers under Regulation S, Regulation D, and Rule 144A. Regulation D and Rule 144A offerings are private rather than public, and U.S. investors currently have a limited ability to participate in public primary distribution markets outside the United States. ${ }^{50}$ Third, they argue that deference to home country rules would only be permitted on a reciprocal basis, so U.S. companies would get some offsetting advantage when making distributions abroad. Reciprocity mitigates the problem of the dual standard in the U.S. market, particularly given that the U.S. markets would presumably always be regarded as efficient, but the problem remains. The question is whether it is really a fair trade for U.S. issuers to get access to smaller foreign markets in exchange for foreign issuers having improved access to the U.S. market.

Finally, the Greene proposal would do little to solve the problem of nonstandardized distribution and enforcement rules. Indeed, the objective of the proposal is somewhat different from the objective for reform considered in this article. It would like to relax the requirements for foreign issuers selling stock in the U.S. marketplace, whereas my objective is to achieve OSI.

3. Broader Extensions of Mutual Recognition. Three broader versions of mutual recognition have been advanced that would permit a firm to issue securities in any market under: (1) whatever country's rules the issuer chooses, the so-called "portable reciprocity" rule advanced by Stephen Choi and Andrew Guzman; ${ }^{51}$ (2) the rules of the issuer's place of incorporation,

48. The proposal sought to cut back the Rule 12g3-2(b) exemption from ' 34 Act registration requirements for companies not meeting the efficiency criteria.

49. See Greene et al., Hegemony, supra note 45, at 433-34.

50. See discussion infra Part V.

51. See Choi \& Guzman, supra note 10, at 907. 
advocated by Roberta Romano $;^{52}$ or (3) the rules of the issuer's home country as determined by the corporation's nationality, proposed by Merritt Fox. ${ }^{53}$ The only real difference between the three proposals is the degree of choice.

Absent consideration of which countries will choose to participate in these regimes, choice is totally unconstrained under the Choi and Guzman "portable reciprocity" proposal because an issuer can choose the rules of any country. Thus, a U.S. issuer could issue securities in France under Antiguan rules. The Romano proposal does have an important constraint: The issuer can use only the rules of its place of incorporation. While Romano envisions that issuers would be free to choose any place to incorporate regardless of the location of their "seat"- as in the United States but not in Europe-once the incorporation decision has been made, further choice of rules would be constrained.

Fox's approach provides for the least choice, because "nationality" would be determined by basic business facts, such as where the entrepreneurs who formed the business reside, where the current headquarters are located, and where the bulk of the firm's operations are conducted.

Insofar as these proposals would result in a wide range of actual usage of different countries' rules, investors would face additional search costs, and risk having a lack of information. We have already discussed the problems of dealing with this situation by positing discounting and diversified portfolios. Even if the discounting mechanism worked, so that issuers would have to pay more for their capital if they chose unclear or obscure rules, issuers bent on fraud would not care; they would take their expensive money and run. It would be politically impossible for a host country to allow such a result.

In reality, investor choice will be fundamentally constrained. Investors will be able to use only the rules of home countries where both host and home countries have agreed to accept such arrangements. At the very least, host countries like the United States would have to agree to allow sale of securities in their territories under a broad range of foreign rules. This proposal is exceedingly unlikely to be adopted by the United States given the fact that the current MJDS arrangement for Canada does not fully accept Canadian disclosure rules, that the SEC has refused to extend its partial acceptance of Canadian rules to other countries, and that the SEC is even questioning whether to keep the MJDS for Canada. ${ }^{54}$ Guzman and Choi recognize this reality by holding out the prospect that their system need not apply to purchases by individual investorsthat is, public primary markets. ${ }^{55}$ This concession, however, makes their proposal unnecessary because issuers in private markets choose their own level of disclosure, free from any country's rules. Countries generally permit this choice because they see no need to protect institutional investors.

52. See Romano, supra note 2, at 2419.

53. See Fox, supra note 3 , at 702 .

54. See Alden, supra note 29.

55. See Choi \& Guzman, supra note 10, at 943. 
If these proposals were to work in any sensible way, countries would also have to agree to enforce the rules that issuers choose and to decide which particular country or countries will enforce them. Let us focus on administrative enforcement, a key element of securities regulation. The assurance of adequate administrative enforcement is close to impossible under the Choi and Guzman proposal. Assume that we had a French company issuing securities in the United States under Antiguan rules. Suspending disbelief about whether the United States would accept the adequacy of Antiguan disclosure rules, which country would enforce the Antiguan rules? If enforcement responsibility were left with Antigua, there would almost certainly be no enforcement due to the lack of resources and interest of Antigua. ${ }^{56}$ This problem cannot be solved by requiring issuers to pay fees to Antigua to enforce the rules. ${ }^{57}$ Even if Antigua received a fee, it would offer little assurance that Antigua would actually enforce its rules. In principle, the U.S. or French authorities could enforce the Antiguan rules, but it is hard to see how this would work in practice. Suppose that under Antiguan rules, prospectuses are filed and reviewed by Antiguan authorities. How does the SEC or the Commission des Opérations de Bourse ("COB") make sure that Antiguan authorities have reviewed the prospectuses? In theory, the SEC or COB could review the prospectuses under Antiguan rules, but this would be extremely burdensome because one could not expect either agency to have the necessary detailed knowledge and understanding of those rules, particularly as those rules may have evolved under Antiguan practice.

One possible, but inadequate, response to this problem might be just to leave to Antigua how and to what extent to enforce its rules. Because the United States must, under this proposal, accept the rules of any jurisdiction, those rules in practice (as enforced) could amount to no rules at all. In short, the authors would argue that Antiguan rules, as enforced by Antigua, must be accepted by the United States. But this argument only pushes us back to the fundamental problem that neither the United States, nor probably any other country with a significant investor base, will allow public distribution of securities in its markets under virtually no rules at all. The enforcement problems are almost as severe under the Romano proposal-all one eliminates is the possibility of French involvement-because only an issuer incorporated in Antigua (but not necessarily doing any business there) would be permitted to issue securities in the United States under Antiguan rules.

One should insist that no country's rules may be used unless that country assures other countries that the rules will be enforced. It is unlikely, however, that credible assurances could be given in practice. It might be easy to elimi-

56. See SECURITIES REgulation, supra note 20, at 1240-44; see also, Cox Regulatory Duopoly, supra note 14 , at $1239-44$.

57. But see Choi \& Guzman, supra note 10, at 933 (arguing that "enforcement officials in a regime jurisdiction can charge a fee to issuers seeking to avail themselves of the regime's securities apparatus and enforcement resources"). 
nate the use of rules of "offshore centers" such as Antigua ${ }^{58}$ but what about such "onshore centers" such as Luxembourg or Hong Kong?

Of the three proposals, the Fox "nationality" proposal seems to be the least objectionable on enforcement grounds. All issuers would at least come from countries where they did most of their business or had established their headquarters, thus eliminating smaller "haven" countries with less enforcement capability. Yet the same basic problem remains: How can the host country (the place where the securities are offered) be assured of enforcement by the home country (the issuer's home country)? A similar issue has plagued banking regulation when banks operate abroad through branches. ${ }^{59}$ In the banking context it is accepted that the major regulatory responsibility for assuring solvency falls on the home country, ${ }^{60}$ because this is where the bank's major operations are located. The host country, however, is concerned with the safety of its consumers (depositors in the branches of the foreign banks), which in turn depends on the adequacy of regulation by the home country. This problem has been addressed by host countries such as the United States by unilaterally conditioning foreign branch entry and continued operation on a determination of the adequacy of foreign regulation. And countries such as the United States have established cooperative relationships with-and insisted on information flow from-foreign regulators to aid in such determination. As a complement to such unilateral action, international agreements among regulators have been reached to facilitate their need for information exchanges. ${ }^{61}$

One should not, however, conclude that this home country control approach to international banking regulation is directly transferable to international securities regulation. The host country's interest in depositor safety is quite limited if deposits in branches of foreign banks are uninsured, as is the case in the United States. Indeed, in 1991, largely as a result of the BCCI affair, the United States shifted from a system in which deposits could be insured by branches of foreign banks to one in which they could not. ${ }^{62}$ The United States forced foreign banks to offer insured deposits through U.S. bank subsidiaries, which are

58. Offshore, in this context, means small islands with little domestic economic activity.

59. See Hal S. Scott, Supervision of International Banking Post-BCCI, 8 GA. ST. U. L. REV. 487 , 491 (1992) (noting that in the case of branches, the host country is largely at the mercy of the home country).

60. See Basle Committee on Banking Supervision, Principles for the Supervision of BANKS' ForeIGN ESTABlishmeNTS (THE CONCORDAT) IV 1 (1983); see also Sydney J. Key \& Hal S. Scott, International Trade in Banking Services: A Conceptual Framework 23, (Group of Thirty, Occasional Paper 35, 1991).

61. Examples of such international agreements among regulators include a Memorandum of Understanding between the United States and Canada dated April 30, 1998, a Statement of Cooperation between the United States and Argentina dated September 3, 1999, a Memorandum of Understanding between the United States and Germany dated August 7, 2000, two Statements of Cooperation between the United States and Chile dated March 10, 1997 and April 16, 1998, and a Memorandum of Understanding between the United States and the United Kingdom dated November 19, 1996 (on file with author).

62. See Foreign Bank Supervision Enhancement Act of 1991, Pub. L. No. 102-242, 105 Stat. 2286 (codified as amended in scattered sections of 12 U.S.C.). 
regulated by the United States. Thus, today, the United States only accepts home country control for international banking where no retail depositors can be injured due to the inadequacy of foreign regulation. It is therefore highly unlikely that home country enforcement will be accepted where U.S. public investors could be at risk for poor foreign enforcement of rules. ${ }^{63}$

In principle, the European Union does accept home country rules and enforcement for cross-border securities issues. However, as previously discussed, there have been very few cross-border public issues under that regime, due to the cost of translation and the persistence of local requirements. Further, the European Union has a political and economic infrastructure with supranational institutions such as the Commission and the Court of Justice, and close ties among regulators, that make the home-country approach more feasible than it would be on an international scale, where such arrangements are lacking.

Another enforcement problem is how private claims against issuers get resolved. Choi and Guzman consider a number of different alternatives, but suggest that the "regime jurisdiction," or the place where the securities regulations governing the issue are located, would be the appropriate place to litigate such an action. ${ }^{64}$ The authors contend that this rule should be a default rule only, and that issuers who wish to contract around such a rule can do so if they desire. They argue that this is the most acceptable alternative because the regime jurisdiction officials have the best understanding of the regime's rules and regulations. Further, they contend that enforcement will occur with more zeal, owing to the fact that the courts will be "upholding [the regime's] own laws, which has a positive effect on the country's legal system generally." ${ }^{\circ 5}$ Can one really imagine an effective private enforcement regime that relies on litigation in Antiguan courts?

Romano recognizes that under her approach, the choice of fora basically would be limited to the issuer's place of incorporation. ${ }^{66}$ She feels, however, that the burden this would place on the ability of an investor to litigate a claim would simply be built into the issuer's cost of capital. Consequently, she notes that foreign companies seeking, for example, U.S. capital, "might therefore find it in their self-interest to ensure that U.S. investors could prosecute securities claims in U.S. courts." ${ }^{97}$ Romano recognizes problems with this approach, particularly whether U.S. courts would accept jurisdiction of these claims.

63. Any home-country regime must, of course, determine what is the home country. In the banking context this is relatively clear because every bank seeking to do business abroad will be able to specify its home country regulator; for example, the regulator to which it reports and by which it is examined and regulated on a continual basis. This issue would be trickier in the securities regulation context, where the question of who is the issuer's home country for the purpose of securities regulationwhich is determined by somewhat unclear criteria-would only come up at the time of an international issue. One virtue of the Romano place-of-incorporation approach is that it would eliminate this problem.

64. Choi \& Guzman, supra note 10 , at 930.

65. Id.

66. See Romano, supra note 2, at 2422 .

67. Id. 
To a significant extent, the issue of acceptability of foreign rules depends on the capability of foreign enforcement. Even if the substance of foreign rules is acceptable, host countries need to be assured that those rules will be enforced. One way to understand our present international system of host country rules and host country enforcement is through the reluctance of host countries to depend on enforcement of rules by other countries.

One final point about these proposals: Like the MJDS, none of them addresses the problem of non-standardized distribution rules.

\section{V \\ OFFSHORE FREE-ZONE}

The third alternative for achieving OSI is an offshore free-zone. Under this approach, countries would permit issuers to offer securities to the public-including residents of their own countries-offshore, subject only to minimum disclosure requirements. This proposal would require substantial change in U.S. regulation because, under Regulation S, the United States currently imposes significant restrictions on offshore primary distributions to U.S. residents.

\section{A. Regulation $\mathrm{S}$}

Under Regulation S, which exempts certain offerings of securities from registration requirements under the Securities Act of 1933 ("33 Act"), domestic and foreign issuers face substantial restrictions when making offshore public primary distributions to U.S. residents. Regulation S imposes general and specific conditions on such offerings. The specific conditions depend on the type of issuer and securities.

1. General Conditions. The general conditions of Regulation S, Rule 903, require that any offer or sale by the issuer, a distributor, any of their affiliates, or any person acting on behalf of any of the foregoing, be made in an "offshore transaction" without "directed selling" efforts in the United States. ${ }^{69}$ To satisfy the requirement of "offshore transaction," the offer must not be made to a person in the United States, and: (1) either the buyer must be outside the United States (or the seller must reasonably believe this is the case); or (2) the transaction must be "executed in, on or through a physical trading floor of an established foreign securities exchange that is located outside the United States." "Directed selling" efforts means activities to condition the U.S. market, such as placing an advertisement in a publication with a general circulation in the United States or conducting a roadshow in the United States.

The general conditions do not permit making a primary distribution to U.S. residents who are in the United States-all but a small percentage of U.S. resi-

68. 17 C.F.R. $§ 230.901-905$ (2000).

69. Id.

70. 17 C.F.R. $\S 230.902(h)(2000)$. 
dents- unless the transaction is executed on the physical trading floor of an established foreign securities exchange. In adopting Regulation S, the Commission believed that primary offerings abroad were infrequently executed through such exchanges. ${ }^{71}$ Primary market transactions almost never take place on an exchange because securities are sold at a fixed price through the underwriting process. Only if there were unsold allotments might the underwriter seek to sell the securities at a "market" price on an exchange. Thus, in reality, the general condition can only be satisfied if the buyer is outside the United States (or the seller reasonably believes that this is the case).

2. Specific Conditions. If the distribution is truly international (not targeted at just one country), or involves "substantial U.S. market interest" ("SUSMI"), it will be subject to offering restrictions ${ }^{72}$ and may be subject to transfer restrictions that apply during a "distribution compliance period." There is no SUSMI in a foreign company's equity securities if the issuer reasonably believes that in its most recent fiscal year, the United States did not constitute the single largest market for the class of equities, and that either less than $20 \%$ of the trading in the class took place in the United States or more than $55 \%$ of the trading took place in a single foreign country. ${ }^{73}$ This test means that IPOs of foreign issuers will never have SUSMI. It also means that even foreign companies making secondary offerings, other than those from emerging markets, will rarely have SUSMI, since most of the trading in their shares will not be in the United States. ${ }^{74}$

So-called Category I securities (those that are distributed in only one foreign country or have no SUSMI) have no distribution compliance period, and therefore no offering conditions or transfer restrictions. Again, this includes most foreign securities. The distribution compliance period for other equities is forty days for so-called "Category II" securities, those issued by a reporting foreign issuer - a foreign issuer subject to the broad disclosure requirements of the Securities Exchange Act of 1934 ("“34 Act") $)^{75}$-and one year for all other issuers, so-called "Category III" securities. In addition, it should be understood that Section 4(3) of the ' 33 Act prohibits any U.S. dealer from selling unregistered securities to investors for forty days. This prohibition applies even to Category I securities, for example, IPOs of foreign issuers. ${ }^{76}$

71. See supra text accompanying note 59; Exchange Act Release No. 37,942, 55 Fed. Reg. 18,306 (May 2, 1990).

72. The offering restrictions, Rule $902(\mathrm{~g}), 17$ C.F.R. $\$ 230.902(\mathrm{~g})(2000)$, require, with respect to all unregistered publicly distributed securities, that (a) each distributor agree in writing that it will comply with Regulation S and (b) offering materials include statements that the securities are unregistered and may not be offered or sold in the United States or to U.S. persons during the distribution compliance period.

73. 17 C.F.R. § 230.902(j)(i)-(ii)(2000).

74. See GREENE ET AL., supra note 1, at 5-14.

75. A foreign issuer means a foreign government or foreign private issuer. For the definition of a foreign private issuer, see supra text accompanying note 26.

76. See GREENE ET AL., supra note 1, at 5-27. 
The rationale for these distribution compliance periods for U.S. investors is not altogether clear. The distribution compliance periods could be based on a consideration of when the securities have "come to rest," a concept rooted in the law for public distributions within the United States. Generally speaking, one cannot have public sales of unregistered securities until the initial distribution of those securities has been completed, i.e., until the securities have come to rest. ${ }^{77}$ This idea is based on the notion that public sales of unregistered securities is only permissible after the initial distribution of the securities is complete. It is therefore necessary to determine when that is. Obviously, if the initial distribution were considered to be complete in a very short period, say one day, the registration requirement for the initial public distributions would be largely irrelevant. Under the Rule 144 safe harbor, the minimum holding period before public resales are permitted, subject to certain amount restrictions and information requirements, is one year. After two years, these restrictions and requirements are removed for all sales other than those by affiliates of the issuer. $^{78}$

The Regulation S distribution compliance periods, however, are shorter than one year in many cases, for example, forty days for securities of a reporting foreign issuer. After forty days, these securities can be resold abroad to U.S. purchasers, as long as the sale is made on a designated offshore securities market. $^{79}$ The ability to resell to U.S. purchasers outside the United States after forty days suggests that the distribution compliance periods are not really motivated by coming to rest concerns. If so, the distribution compliance period for all securities (not just those in Category II) would be much longer, probably at least one year, to be consistent with Rule 144 .

In fact, it seems that the Regulation $\mathrm{S}$ compliance periods are designed to protect against flowback of securities into the U.S. market. The SEC has stated that " $[\mathrm{t}]$ he purpose of the distribution compliance period is to ensure that during the offering period and the subsequent aftermarket trading that takes place offshore, the persons relying on the safe harbor-issuers, distributors and their affiliates-are not engaged in an unregistered, non-exempt distribution into the United States capital markets." The SEC has adopted these restrictions in order to prevent flowback of the securities into the United States. ${ }^{81}$ Flowback is minimized, according to the SEC, by the imposition of offering conditions and transfer restrictions during the distribution compliance period. The more concern there is over flowback, the longer the distribution compliance period and the more rigorous the restrictions.

77. See SeCURities Regulation, supra note 20, at 443.

78. 17 C.F.R. 230.144(c),(d),(e) (2000).

79. See infra text accompanying note 92 .

80. Securities Act Release No. 7705, Exchange Act Release No. 39,668, 63 Fed. Reg. 9632, 9635 (Feb. 25, 1998).

81. See Securities Act Release No. 6863, Exchange Act Release No. 37,942, 55 Fed. Reg. 18,306 (May 2, 1990). 
No transfer restrictions are imposed on Category II securities, but they are imposed on Category III securities. For equity securities, ${ }^{82}$ these restrictions generally require that: (1) no offer or sale be made to a U.S. person (domestic resident) or for the account of a U.S. person; (2) the purchaser certifies that he is not a U.S. person or acquiring for a U.S. person; (3) the purchaser agrees to abide by Regulation S (which prevents reselling to a U.S. person during the distribution compliance period); (4) for domestic issuers, the certificates contain a legend to the effect that transactions are prohibited except in accordance with Regulation S (seemingly prohibiting certificateless distributions) s3 $^{83}$ and (5) the issuer refuses to register transfers of securities not made in accordance with the provisions of Regulation $\mathrm{S}$ or, if the securities are in bearer form or if foreign law prevents the issuer from refusing registration, other reasonable transfer restrictions are adopted, such as legends.

The net result of these provisions is that unregistered securities offered internationally (in more than a single market), where there is substantial U.S. market interest, cannot be resold (for up to one year in the case of certain equities and forty days for most debt) in public primary markets to U.S. residents, whether the offers or sales occur inside the United States or outside the United States. This prohibition may be implemented through both offering and transfer restrictions for certain issuers, but the same basic prohibition applies to sales to U.S. investors inside or outside the United States. This is true despite claims by the SEC that Regulation $S$ represents a territorial approach to securities regulation.

3. Resales After the End of the Distribution Compliance Period. After the distribution compliance period is over, Regulation $\mathrm{S}$ continues to apply to resales, but its restrictions on resales to U.S. persons are considerably relaxed. Offering and transaction restrictions are removed. While no offer can be made to a person in the United States and no directed selling efforts may be made by the seller in the United States, the seller can sell the shares on a "designated offshore securities market" to anyone, including a U.S. person, as long as the

82. For debt securities, no offer or sale must be made to a U.S. person or for the account or benefit of a U.S. person and the securities must be represented by a temporary global security, which is not exchangeable for definitive securities until the end of the distribution compliance period, and, for persons other than distributors, until certification of beneficial ownership of the securities by a non-U.S. person. The use of the temporary global security, under which transfers of securities are registered, allows more effective control of the Regulation S restrictions on sales to U.S. persons.

83. The SEC has granted an exemption from the legend requirement to the European Association of Securities Dealers Automated Quotation System ("EASDAQ") in connection with its listing of IPOs of U.S. issuers. EASDAQ could not comply with the requirement because it is a screen-based market trading system in certificateless shares. EASDAQ proposed, and the SEC accepted, alternative restrictions to ensure that U.S. investors did not participate. The SEC also noted that U.S. firms were not permitted to participate in the EASDAQ market and there were no EASDAQ screens in the United States. Presumably, this was important to the SEC insofar as it made it less likely for U.S. persons to participate in EASDAQ. Of course, all major U.S. broker/dealers have European affiliates that do participate in EASDAQ and those affiliates have screens. It would not be difficult for the U.S. firm to hand off a trade to its affiliate. See EASD Automated Quotation, SEC No-Action Letter, [1999 Transfer Binder] Fed. Sec. L. Rep. (CCH) II 77,586 (July 27, 1999). 
sale has not been prearranged to such buyer. ${ }^{84} \mathrm{~A}$ "designated offshore securities market" must be organized under foreign law, be associated with a generally recognized community of securities professionals, for example, brokers, dealers, and banks; be subject to regulatory oversight and legal standards; require reporting of transactions on a regular basis to regulators; and have a price quotation and organized clearance and settlement system. Regulation S itself states that certain markets qualify, including stock exchanges in all major markets, such as the London Stock Exchange, Paris Bourse, and Tokyo Stock Exchange. ${ }^{85}$

Thus, after the expiration of any applicable distribution compliance period, resales of securities distributed in public primary markets outside the United States may generally be bought and sold by U.S. residents on foreign exchanges, without violation of the ' 33 Act, as long as no efforts are made to sell the securities in the United States to U.S. residents.

Indeed, once the Regulation S distribution compliance period ends, persons who have purchased Regulation $S$ securities of foreign issuers in the secondary market offshore may immediately make public resales of those securities in the United States itself. Such securities are not "restricted securities" within the meaning of Rule 905-that Rule only applies to domestic issuers ${ }^{86}$ - and are thus not subject to the one-year minimum holding period for "restricted securities" under Rule $144 .^{87}$

Such securities may, however, become subject to the ' 34 Act if they are owned by more than 300 U.S. shareholders, ${ }^{88}$ which will require the issuer to comply with U.S. disclosure requirements, including U.S. GAAP reconciliation requirements. Under Rule 12g3-2(b), however, such securities are exempt from such U.S. disclosure requirements as long as the issuers file with the SEC whatever reports they file in their home countries and the securities are not listed on a U.S. exchange, or traded on the OTCBB. ${ }^{89}$ Such securities can generally only be traded in the illiquid pink sheets market, where there are no continuous price quotations.

Domestic issuers, whose Regulation S offerings are Category III securities, and thus subject to a one-year distribution compliance period, are subject to Rule 144. At the end of one year, domestic issuers could make public resales in the United States subject to Rule 144 requirements, because the Rule 144 minimum holding period is also one year.

84. 17 C.F.R. $\$ \S 230.902(h), 230.904$ (2000).

85. 17 C.F.R. $\$ 230.902$ (b) (2000).

86. 17 C.F.R. $\$ 230.905$ (2000).

87. 17 C.F.R. $\$ 230.144$ (a)(3) (2000).

88. See Securities Exchange Act of 1934, 15 U.S.C. $\$ 78 l$ (1994).

89. The Rule 12g3-2(b) exemption from ' 34 Act registration does not apply to listed securities, and since 1998, it has not applied to OTCBB. See Exchange Act Release No. 38,456, 64 S.E.C. Docket 490 (Mar. 31, 1997). 
B. Use of the Internet

The Regulation S exemption from '33 Act registration requirements only applies where there are no public sales to persons in the United States. The SEC has issued an Interpretation to clarify when the posting of offering or solicitation material on Internet Web sites would not be considered activity taking place in the United States. ${ }^{90}$

The Interpretation first provides that an issuer must employ procedures "reasonably designed to avoid targeting the United States." This requirement generally will be met if the Web site includes a prominent disclaimer that the offer is directed only to countries other than the United States and the Web site offeror implements certain procedures, such as ascertaining the purchaser's residence prior to the sale.

Where, however, the securities are unregistered publicly distributed securities issued by domestic issuers, more restrictive requirements apply. U.S. issuers are required to implement password-type procedures that are reasonably designed to ensure that only non-U.S. persons can obtain access to the offer. Persons seeking access to the Internet offer would have to demonstrate that they are not U.S. persons before obtaining the password for the site. The SEC justified these additional restrictions on three grounds: (1) the substantial contacts a U.S. issuer has with the United States; (2) the strong likelihood that securities of U.S. issuers initially offered and sold offshore will enter U.S. trading markets (reasoning similar to that underlying the adoption of offering and transaction restrictions under Regulation S); and (3) U.S. issuers and investors have a much greater expectation that securities offerings by domestic issuers will be subject to U.S. securities laws.

VI

\section{A NEW PROPOSAL}

I would like to put forward the following proposal, in lieu of pursuing harmonization or any of the variations of home-country or issuer choice of rules: U.S. investors would be free to participate fully in the primary offshore markets for foreign issues-removing the waiting period and all restrictions on offshore sales to U.S. investors. Prohibitions on directed selling efforts by foreign issuers would also be removed. The objective is to allow the development of a deep and active primary offshore market that will go a long way toward establishing OSI for foreign securities. This proposal would require modifications to Regulation S, Section 4(3) (at least through revision of Rule 174), and the Internet Release.

90. Securities and Exchange Commission, Statement of the Commission Regarding Use of Internet Web Sites to Offer Securities, Solicit Securities Transactions or Advertise Investment Services Onshore, 63 Fed. Reg. 14,806 (Mar. 27, 1998). 


\section{A. Minimum Disclosure Requirement}

The rationale for restricting U.S. investor access to primary distributions outside the U.S. is basically rooted in a concern over whether adequate disclosure would be made to such investors absent registration. This concern could be addressed by requiring that all foreign primary public distributions in which U.S. investors were free to participate meet certain minimum disclosure requirements. Minimum disclosure requirements are already assumed under the MJDS and were rightly an important feature of the Greene proposal. As has been argued earlier in this article, we have a readily available benchmark for such disclosure in the form of the "international standard" used in the private primary markets. Disclosure rules could be reverse engineered from market practices and would differ depending on the type of issue (IPO versus secondary offering), security, and issuer.

The availability of a market benchmark makes the more radical reforms based on issuer choice of disclosure rules unnecessary. Those theories are predicated on the need for regulatory competition to produce the right level of disclosure. One is far better off mimicking actual market-based disclosure levels than relying on regulatory competition to produce this result. As previously argued, the regulatory competition model is, in any event, theoretically flawed and impractical. ${ }^{91}$ On a more general note, the SEC might well benefit by testing its disclosure rules for the domestic market against the private market disclosure rules, but that is a subject beyond the scope of this article.

\section{B. Proposal only Applicable to Foreign Private Issuers}

At least initially, I would restrict this exemption from Regulation $\mathrm{S}$ to foreign private issuers and continue to apply Category II conditions on sales in the United States to U.S. persons during the "distribution compliance period." Thus, during the forty-day Category II distribution compliance period, U.S. persons, wherever located, could buy and resell foreign securities outside the United States, but could not resell those securities in the United States. After the expiration of the forty-day period, sales could be made back into the United States as at present. Thus, U.S. persons would be free, without restriction, to participate in public primary distributions by foreign issuers abroad. Also, any purchasers of securities in the primary market could resell their securities abroad at any time to anyone, including U.S. persons. This should create a public primary distribution market outside the United States in which all investors can participate. Since all investors, including U.S. investors, can also immediately participate outside the United States in the secondary market for such securities, the market should also have the required liquidity.

Domestic issuers would still have to comply fully with Regulation S, which would preclude making offshore public primary distributions to U.S. investors. While there would be discrimination against use of U.S. issuers' access to the

91. See supra note 10 and accompanying text. 
offshore public primary markets, this discrimination would not have a serious impact on U.S. issuers. Domestic issuers already must comply with a principal feature of the U.S. regulatory regime-the necessity to state accounts under U.S. GAAP accounting principles. Large-reporting domestic issuers can minimize primary distribution costs through shelf registration, and thus are unlikely to see great advantages from issuing abroad. For IPOs, domestic issuers would not get weaker disclosure standards (apart from U.S. GAAP reconciliation requirements) from issuing abroad given that the "international standard" for IPOs-requiring compliance by all issuers-is close to that for U.S. public offerings. In comparison, the discrimination against U.S. issuers under the home country proposals - under which foreign issuers would be able to distribute securities within the United States under more relaxed standards than domestic issuers-would be more of a competitive threat to U.S. issuers who would be put at a competitive disadvantage in their own markets.

\section{Investor Protection Considerations}

It will surely be argued that because U.S. investors are free to participate abroad in primary distributions of foreign issuers, whatever protection they are assured within the U.S. domestic market will be totally eviscerated. This argument should fail because the proposal requires minimum disclosures based on market standards.

Additionally, the proposed change is rather small; one is merely allowing U.S. persons to make purchases of foreign securities in offshore markets without waiting, at the most, forty days. All debt securities, whether of reporting or non-reporting foreign issuers, are subject only to a forty-day distribution compliance period. The same forty-day waiting period applies to equities issued by a reporting foreign issuer. Equities issued by a foreign issuer in which there is "no substantial U.S. market interest," which includes all foreign IPOs, can already be purchased offshore without a waiting period. ${ }^{92}$ Furthermore, U.S. investors today can fully participate in offshore primary distribution markets for Category II securities if they do so through non-U.S. broker-dealers. ${ }^{93}$

The investor protection value of a forty-day waiting period is ostensibly that, after forty days, the price of the securities is more reliable because securities have already traded for some period in the secondary market. However, there is no reason that new issues of securities would be more volatile in the forty-day period after their issue than they are thereafter, particularly where secondary offerings are concerned, so that prior issues of the class of securities offered are

92. 17 C.F.R. $\S \S 230.903(b)(i), 230.902(j)(i)(2000)$.

93. The general prohibition of Rule 903(a), 17 C.F.R. $§ 230.903(a)$ (2000), only applies to issuers, distributors, and their affiliates or agents. So Regulation S would not even reach a U.S. broker-dealer who was not a participant in the distribution. However, Section 4(3) of the ' 33 Act, together with Rule 174 , provides that during a 40-day period following commencement of the offer, no U.S. dealer can deliver a prospectus. The effect is for Category I and II, if a U.S. dealer is complying with the rules, he cannot sell or execute an offer to buy during that period. I thank both Howell Jackson and Ed Greene for bringing this point to my attention. 
already trading in the market. And even if this were the case for IPOs, U.S. investors should not be deprived of investing in volatile stocks; they are, after all, completely free to buy such stocks in the U.S. new issue market, and are more generally free to buy volatile stocks in the U.S. secondary market.

Perhaps, the objective is not to protect U.S. investors from volatility per se, but to ensure that the market has forty days to incorporate material information into the price of the stock. To begin with, the minimum disclosure requirements would require that all material information about the issue be disclosed at the time of its distribution. Further, there is no reason to assume that all material information about a stock will be incorporated into its price in forty days. Certainly new material information can develop after forty days, and there is no reason to assume that all material information that may exist prior to the expiration of forty days will be fully incorporated in the price of the stock by the end of forty days.

Even if one were to assume that some loss in investor protection might occur from removing the forty-day waiting period, the loss would seem less than what might occur under the various home-country rule approaches (where there was no minimum disclosure), and the amount of loss would be small compared to the gains in investor overall welfare from achieving OSI.

\section{Why Offshore and Not Onshore?}

Can one defend a system in which public investors have mandated U.S. disclosure rules for onshore primary issues, but only minimum disclosure rules for offshore issues? I think so. The SEC has already acknowledged that there are jurisdictional concerns in extending U.S. disclosure rules to offshore markets; this is the reason that Regulation S supposedly follows the territorial principle. In reality, Regulation $S$ does not follow that principle because it restricts participation of U.S. investors in offshore primary markets. Indeed, one could view Regulation $S$ restrictions as a type of capital control, restricting the flow of U.S. investor funds to foreign markets. This proposal takes territorial considerations more seriously and would remove such capital controls. No other major investor country currently restricts offshore activities of their domestic investors. Indeed, as we have seen, the ability of European public investors to buy securities in offshore markets, for example, German investors buying securities issued in London, makes it generally unnecessary to have European-wide retail distributions.

In addition, investors' expectations are probably different when they buy securities in their own country compared to buying securities abroad. They expect to be protected by their own laws when buying securities (or anything else) in their own countries, but do not have such an expectation when making purchases abroad. While technological advances have made purchases abroad more seamless than before-investors can call their brokers who may be directly able to access foreign markets from their computers in the United States, or at most, will have to pass the order onto foreign affiliates-the investors 
should understand that they are purchasing securities outside the United States, which are not fully subject to U.S. rules. Concern about whether investors would truly understand this can be met by requiring professional intermediaries to make this clear to their clients. ${ }^{94}$ Of course, investors could bypass U.S. intermediaries and place orders directly with foreign brokers. But the fact that the investor is taking significant steps to seek out the securities abroad and willing to trade with a foreign broker makes protection of such an investor less compelling.

\section{E. Directed Selling in the U.S.?}

Another important question is whether foreign issuers should be free to engage in directed selling efforts for their securities in the United States, even if U.S. investors will only be free to buy such securities offshore during the waiting period. If directed selling efforts are prohibited, one can argue that foreign issuers will not be able to attract the attention of a sufficient individual investor community to allow a deep and active primary offshore market to develop. On the other hand, the more directed selling, the greater the possibility that U.S. investors might participate, to their detriment, in such markets.

My view is that investors should not be deprived of information about investment possibilities and that one does not protect investors by depriving them of information. We should be fostering a disclosure regime, not a nondisclosure regime. Once the decision has been made to allow U.S. investors to participate in offshore markets, they should know what opportunities exist in such markets. Consistent with this proposal, I would also remove Internet restrictions on directed promotion of foreign issues to U.S. investors. However, one could retain the prohibition on actual sales to U.S. investors over the Internet during the waiting period. This would ensure that U.S. investors would participate in the market through broker-dealers, who would be more likely to alert investors to potential fraudulent or highly risky offers.

\section{F. Distribution and Enforcement}

One major virtue of this proposal, compared to any reform affecting the distribution of foreign securities in the United States, is that offshore primary sales of foreign securities would escape any of the U.S. distribution prohibitions; for example, research report restrictions or prohibition of sales before receipt of a prospectus. This permits a fuller development of OSI than could be achieved by disclosure reforms within the U.S. market. Investors from all countries could buy securities in the offshore market under the same set of distribution procedures. Generally, uniformity of distribution procedures would otherwise only be achievable through harmonization, which is highly unlikely to occur.

94. See Howell E. JACKSON AND EdWARD L. SyMOns, JR., REgulation Of FinANCIAL INSTITUTIONS 689-95 (1999) for other types of required disclosures by intermediaries. 
What about enforcement? Who would enforce compliance with the "international" minimum disclosure standards required under the proposal? The answer should be all jurisdictions whose investors buy the securities. Thus, the SEC could take action to prevent or stop distributions that do not comply with these rules, or seek redress for the failure to comply after the fact. The difficulties encountered when issuers are free to choose rules, or to use home country rules, do not exist. No jurisdiction can claim special expertise in "international" disclosure rules, which are based on market practice. This rule would avoid reliance on weak enforcement jurisdictions, such as Antigua, to enforce their rules or on strong enforcement jurisdictions, such as the United States, to enforce some other country's rules.

It is true that there may be uneven and different enforcement by several jurisdictions of the same international rules. But this should not deter any issues, given the fact that the rules themselves are based on market practice. In any event, such inconsistencies are preferable by far to proposals, like those of Choi \& Guzman, Romano, and Fox, where no meaningful enforcement can be assured. If disclosure is good, enforcement of disclosure is also good.

As for general liability standards, U.S. 10b-5 rules would continue to apply to the extent that there were sales to U.S. investors resident in the United States, particularly if the foreign issuer used directed selling efforts in the United States to reach such investors. ${ }^{95}$ Section 11, however, would not apply because under the modified Regulation $\mathrm{S}$ proposed here, registration of foreign issues distributed offshore would not be required. Either private litigants or the SEC could enforce 10b-5.

\section{G. Big Whoop?}

One criticism of the proposal could be that it does not change things very much and, therefore, might have very little impact. To recount, IPOs of foreign issuers are Category I securities (because there is no substantial U.S. market interest due to the lack of any trading in the past) and can currently be bought offshore without any waiting period. Further, any U.S. investor can freely participate in all primary foreign distributions through non-U.S. broker-dealers. This criticism does not withstand scrutiny.

First, my proposal would completely exempt from registration for the first time all foreign issues, not just Category I securities. Second, the ability of U.S. investors to purchase securities in the forty-day period from U.S. brokerdealers, the usual firms with whom they do business, should greatly increase U.S. investor participation. Indeed, the SEC has been reluctant to allow foreign markets such as the Deutsche Boerse to establish terminals in the offices of broker-dealers in the U.S., out of concern that such terminals would be used to

95. See Bersch v. Drexel Firestone, Inc., 519 F.2d 974, 993 (2d Cir. 1975), cert. denied, 423 U.S. 1018 (1975) (effects test covers sales to Americans resident in the U.S.). Bersch still seems to be good law. See Europe and Overseas Commodity Traders, S.A. v. Banque Paribas London, 147 F.3d 118, 128 n.12 (2d Cir. 1998). 
access foreign primary market distributions. Under this proposal, any restrictions on U.S. broker-dealers' access to foreign primary markets would be removed. Participation of U.S. investors also should be significantly aided by dropping the prohibition on directed selling efforts for foreign primary issues.

Further, if investors can participate freely in foreign primary distribution markets through foreign broker-dealers who might not keep them informed, investor protection would be better served by channeling their orders through U.S. broker-dealers who were under a legal obligation to disclose to investors the risks of their investments. The SEC's position-allowing participation only through foreign broker-dealers-can only be justified by the perverse logic that this makes it harder for investors to buy foreign securities. The problem is that the investors who overcome the obstacles will be more poorly informed. ${ }^{96}$

One also might argue that because U.S. investors currently can participate in secondary offshore markets in Category I foreign securities forty days from the initial offering (at the latest), and perhaps immediately after the offering (if they are not considered to be in the primary distribution chain), not much is achieved by permitting them to have access to the initial distribution. Leaving aside the substantial uncertainties of who is or is not in the distribution chain, many investors want the opportunity to buy in the primary markets at a fixed price. The availability of such purchasers can be an important factor in setting the price of the issue, and ultimately determining the global allocation of capital. In short, the proposed rule would make a significant difference.

\section{VII}

\section{CONCLUSION}

This article posits that it would be desirable for issuers in public primary securities markets to be able to issue securities to investors worldwide using one set of optimal distribution procedures and disclosure documents, and one set of liability standards and enforcement remedies. It points out that this state of affairs is currently not possible because the United States conditions public issuance in its territory-and to some significant extent to U.S. investors outside its territory-on compliance with its unique set of distribution procedures, disclosure requirements, and enforcement rules. This is not optimal, as reflected in the different procedures and level of disclosure often used in the unregulated private placement market. If one were to use private market disclosure, based on actual practices, as a basis for determining required public disclosure, the level of disclosure would depend on the characteristics of the issue and the nature of the issuer much more than at present. This article rejects, however, the

96. This same perverse logic underlies the U.S. rules remitting trading in the United States of unregistered foreign securities to the pink sheets. While it may be harder for the investor to find the pink sheets, investors who trade through them must suffer the consequences of illiquid markets. United States investors would be better off if they could trade all foreign securities in liquid markets, that is, exchanges. See Financial Economists Roundtable, Statement on Listing Requirements FOR FOREIGN SECURITIES (July 3, 1993). 
contention that disclosure is unimportant to investor welfare because investors can discount stock prices to compensate for the lack of information; the discounting mechanism simply does not work.

Harmonization of world rules is not the answer to this problem. There is no reason to assume that the world would choose an optimal level of disclosure, particularly because the United States will push for world rules that are closely equivalent to its own. Moreover, there is substantial doubt as to whether worldwide agreement can be reached on the issue of disclosure, let alone distribution and enforcement rules. Undesirable sacrifices of sovereignty to an Uber-regulator might be required, and regulatory innovation that grows out of different approaches by different countries would be lost.

Nor is mutual recognition the answer. Whatever its theoretical virtueswhich I believe are small-the approach is basically unacceptable to the United States, which is contemplating abandoning the MJDS for Canada, rather than expanding it to other jurisdictions. The approach creates basic inequities for domestic issuers. The approach has not even worked in the European Union, which has supranational institutions, despite much fanfare about the single passport. Broader versions of mutual recognition, such as portable reciprocity, founder on problems of enforcement.

I propose instead the establishment of an offshore free zone. This would require that the United States, like other countries, permit its investors to participate in the offshore market for primary distributions free of restrictions other than minimum disclosure requirements. I am aware of no other G-10 country that attempts to restrict investor access to offshore markets. Indeed, such restrictions are a type of capital control that the United States generally opposes. This proposal would require substantial changes in Regulation $\mathrm{S}$, the SEC's Internet Release, and Section 4(3) of the '33 Act (at least through revision of Rule 174). One major benefit of this approach is that it would permit the use of common distribution procedures.

In the electronic world of today, the distribution of foreign securities need not take place in any particular territory; it can be done through computers and the Internet. We should not hinder this development. Instead, we should allow technology to facilitate more optimal arrangements for the primary sale of such securities. 